\title{
ANALISIS PENDAPATAN DAN EFESIENSI USAHA PEMBIBITAN UDANG VANAME (Litopenaeus vannamei) DI KABUPATEN TAKALAR
}

\author{
Abdul Halil dan ${ }^{*}$ Rahmawati \\ Fakultas Pertanian Universitas Muhammadiyah Makassar \\ *e-mail : rahmawati.hodi@unismuh.ac.id
}

\begin{abstract}
Ringkasan
Penelitian ini bertujuan untuk mengetahui produksi, biaya produksi, penerimaan, dan pendapatan usaha pembibitan udang vaname, di Kabupaten Takalar. Penentuan sampel dilakukan secara sensus dimana seluruh jumlah populasi dijadikan sebagai sampel. yaitu berjumlah 12 orang pengusaha pembibitan udang vaname. Analisis data menggunakan analisis penerimaan, biaya produksi dan pendapatan. Berdasarkan hasil perhitungan diketahui bahwa produksi usaha pembibitan udang vaname rata-rata per kolamnya sebesar 1.000 .000 ekor dengan harga 1,3/ekor. Biaya produksi yaitu biaya variable, rata-rata sebesar Rp 8.383.335 dan biaya tetap, rata-rata sebesar Rp 10.100.981. Jadi, total biaya produksi rata-rata sebesar Rp 22.842.648. Total penerimaan petani yaitu produksi di kali dengan harga, rata- rata sebesar Rp 37.750.000; dengan pendapatan rata-rata sebesar Rp 15.343.315.
\end{abstract}

Kata kunci: pembibitan udang vaname, pendapatan,efisiensi usaha 


\title{
REVENUE ANALYSIS AND BUSINESS EFFICIENCY UDANG VANAME (Litopenaeus vannamei) IN TAKALAR DISTRICT
}

\begin{abstract}
This study aims to determine the production, production costs, revenues, and business revenue of vaname shrimp breeding, in Takalar Regency. Determination of the sample is done by census where the entire population is used as a sample. namely a total of 12 vaname shrimp breeding entrepreneurs. Data analysis uses analysis of revenue, production costs and income. Based on the calculation results, it is known that the production of vaname shrimp breeding business on average per pond is 1,000,000 with the price of $1.3 /$ head. Production costs are variable costs, an average of $R p$ 8,383,335 and fixed costs, an average of $R p$ 10,100,981. So, the total total production cost is $R p$. 22,842,648. The total farmer income is production at times with prices, an average of $R p .37,750,000$; with an average income of $R p$. $15,343,315$.
\end{abstract}

Keywords: vaname shrimp breeding, income, business efficiency

\section{PENDAHULUAN}

Pemanfaatan dan pengembangan potensi sumberdaya perairan pantai dan laut yang menjadi paradigma baru bagi pembangunan di masa sekarang yang harus dilaksanakan secara rasional dan berkelanjutan. Salah satu kegiatan yang dilakukan adalah usaha pembibitan udang karena mempunyai prospek usaha yang menjanjikan, selain waktu pembudidayaannya yang relatif singkat, udang juga lebih tahan akan penyakit. Usaha pembibitan udang merupakan kegiatan yang dapat meningkatkan pendapatan, sehingga usaha pembibitan udang dapat menambah kesejahteraan masyarakat karena udang memiliki banyak permintaan di pasar. Udang sudah bukan hal yang asing lagi bagi para petambak, udang introduksi tersebut telah berhasil merebut simpati masyarakat pembudidaya karena kelebihannya, sehingga sejauh ini dinilai mampu sebagai alternatif kegiatan usaha yang positif (Subyakto dkk., 2009).

Budidaya merupakan salah satu kegiatan alternatif dalam meningkatkan produksi perikanan. Syarat terlaksananya kegiatan budidaya adalah adanya organisme yang dibudidayakan, media hidup organisme, dan wadah/ tempat budidaya. Udang Vaname merupakan salah satu jenis udang yang sering dibudidayakan. Hal ini disebabkan udang tersebut memiliki prospek dan profit yang menjanjikan. Kegiatan kultivasi vaname meliputi kegiatan pembenihan dan pembesaran. Untuk menghasilkan komoditas vaname yang unggul, maka proses pemeliharaan harus memperhatikan aspek internal yang meliputi asal dan kualitas benih; serta faktor eksternal mencakup kualitas air budidaya, pemberian pakan, teknologi yang digunakan, serta pengendalian hama dan penyakit (Haliman dan Adijaya, 2005).

Usaha pembibitan udang adalah kegiatan atau usaha memelihara udang di selama periode tertentu, serta memanennya dengan tujuan memperoleh keuntungan. Keuntungan yang dipeoleh dengan adanya usaha ini, sangat bergantung pada pendapatan dan tingkat efisiensi 
usaha. Pendapatan sangat berpengaruh bagi kelansungan hidup masyarakat yang usaha udang Vaname ini, semakin besar pendapatan yang di peroleh maka semkain besar kemampuan para masyarakat untuk membiayai segala pengeluaran dan kegiatan-kegiatan yang akan di lakukan oleh para masyarakat yang usaha pembibitan udang dan darah kehidupan dari suatu usaha. Tanpa pendapatan tidak ada laba, tanpa laba maka tidak ada suatu usaha. Hal ini tentu saja tidak mungkin terlepas dari pengaruh pendapatan dari hasil operasi para pembibit udang Vaname. Sementara efesiensi adalah suatu cara dengan bentuk usaha yang di lakukan dalam menjalankan sesuatu dengan baik dan tepat serta meminimalisir pemborosan dalam segi waktu, tenaga dan biaya. Penelitian ini bertujuan menghitung tingkat pendapatan dan tingkat efisiensi usaha yang diperoleh petani dalam usaha pembibitan udang vaname di Kabupaten Takalar.

\section{METODE PENELITIAN}

\section{Waktu dan Lokasi Penelitian}

Penelitian dilaksanakan pada bulan Juni 2019, di Desa Bonto Sunggu Kecamatan Galesong Utara Kabupaten Takalar. Pemilihan lokasi penelitian dilakukan secara sengaja (purposive) karena petani yang jumlahnya banyak dan tersebar di kecamatan tersebut.

\section{Teknik Analisis Data}

\section{Pendapatan}

Pendapatan merupakan hasil yang di peroleh dalam kegiatan usaha dalam suatu periode. Pendapatan usahatani adalah selisih antara penerimaan dan semua biaya. Adapun fungsi pendapatan yaitu memenuhi kebutuhan sehari-hari dan kebutuhan kegiatan usahatani. Selisih antara penerimaan tunai usahatani dan pengeluaran tunai usahatani disebut pendapatan tunai usahatani (farm net cashflow) dan merupakan ukuran kemampuan usahatani untuk menghasilkan uang tunai. Pendapatan usahatani dibedakan menjadi pendapatan atas biaya tunai dan pendapatan atas biaya total. Dimana pendapatan atas biaya tunai merupakan pendapatan yang diperoleh atas biaya-biaya yang benar-benar dikeluarkan oleh petani, sedangkan pendapatan atas biaya total merupakan pendapatan setelah dikurangi biaya tunai dan biaya diperhitungkan. Pendapatan usahatani dapat dirumuskan sebagai berikut (Soekartawi, 1986; Soekartawi, 2006) :

$$
\begin{aligned}
& \mathrm{Pd}=\mathrm{TR}-\mathrm{TC} \mathrm{TR}=\mathrm{Y} \times \mathrm{Py} \\
& \mathrm{TC}=\mathrm{FC}+\mathrm{VC}
\end{aligned}
$$

$$
\begin{aligned}
& \text { Dimana }: P d=\text { pendapatan usahatani } \quad \mathrm{VC}=\text { biaya variabel (variable cost) } \\
& \mathrm{TR}=\text { total penerimaan (total revenue) } \mathrm{Y}=\text { produksi dalam usahatani }
\end{aligned}
$$

\section{Efisiensi}

Efesiensi adalah ketepatan cara (usaha, kerja) dalam menjalankan sesuatu dengan tidak membuang-buang waktu, tenaga dan biaya. Efesiensi juga berarti rasio antara input dan output 
atau biaya dan keuangan. Selanjutnya efesiensi merupakan perbandingan yang terbaik antara input (masukan) dan output (hasil antara keuntungan dengan sumbersumber yang dipergunakan), seperti halnya juga hasil optimal yang dicapai dengan penggunaan sumber yang terbatas. Dengan kata lain hubungan antara apa yang telah diselesaikan. Dari uraian di simpulkan bahwa efesiensi adalah suatu cara dengan bentuk usaha yang di lakukan dalam menjalankan sesuatu dengan baik dan tepat serta meminimalisir pemborosan dalam segi waktu, tenaga dan biaya. Adapun rumus efesiensi pemasaran metode achrya dimana nilai tersebut diperoleh dari nilai harga pengusaha pembibitan dibagi dengan penjumlahan dari biaya pemasaran dan margin pemasaran yang dapat di rumuskan sebagai berikut (Hasibuan, 2005; Mulyadi, 2007) :

$$
\mathrm{Ep}=\mathrm{Bp} / \mathrm{H} \times 100 \%
$$

Keterangan :

$$
\begin{aligned}
& \mathrm{Ep}=\text { Efesiensi Pemasaran } \\
& \mathrm{BP}=\text { Biaya Pemasaran } \\
& \mathrm{H}=\text { Harga }
\end{aligned}
$$

Analisis data bertujuan untuk memperoleh gambaran yang jelas dari data yang telah disimpulkan dan disusun dalam keseluruhan data. Teknik analisis data penelitian itu teknik analisis pendapatan. Pendapatan merupakan selisih antara penerimaan dengan biaya produksi. Penerimaan merupakan hasil perkalian antara jumlah produksi dengan harga produk tersebut, sedangkan biaya produksimerupakan hasil perkalian antara jumlah faktor produksi dengan hargafaktor produksi tersebut. Pendapatan usahatani dapat dirumuskan sebagai berikut: $\mathrm{Pd}=$ $\mathrm{TR}-\mathrm{TC} \mathrm{TR}=\mathrm{Y} \times \mathrm{Py} \mathrm{TC}=\mathrm{FC}+\mathrm{VC}$ Dimana $: \mathrm{Pd}=$ pendapatan usaha $\mathrm{TR}=$ total penerimaan (total revenue) $\mathrm{TC}=$ total biaya (total cost) $\mathrm{FC}=$ biaya tetap (fixed cost) $\mathrm{VC}=$ biaya variabel (variable cost) $\mathrm{Y}=$ produksi yang diperoleh dalam usahatani Py = harga Y (Endang; 2012).

\section{HASIL DAN PEMBAHASAN}

\section{Analisis Pendapatan Usaha Pembibitan Udang Vaname}

Pendapatan usaha adalah selisih penerimaan usaha dan biaya total usaha, meliputi biaya tetap dan biaya variabel. Sedangkan penerimaan adalah nilai produksi yang dihasilkan dari suatu usaha, jumlah penerimaan dari suatu proses produksi dapat ditentukan dengan mengalikan jumlah produksi dengan harga produksi tersebut. Biaya merupakan semua dana yang dikeluarkan dalam melaksanakan kegiatan usaha. Biaya adalah pengerbonan yang mutlak yang harus dikeluarkan agar memperoleh suatu hasil. Biaya produksi adalah seluruh pengeluaran untuk membiayai proses produksi dalam usaha. Biaya yang dihitung dalam penelitian ini adalah biaya yang dikeluarkan selama satu kali panen yang tergolong kedalam biaya tetap dan biaya variabel.

Biaya variabel adalah biaya yang jumlahnya berubah-ubah sesuai dengan jumlah hasil yang diinginkan. Makin tinggi jumlah output yang dihendaki semakin besar pula jumlah biaya 
variabel yang dekeluarkan. Biaya variabel dalam penelitian ini meliputi telur udang, pakan dan biaya tenaga kerja. Biaya tetap adalah biaya yang jumlahnya selalu sama meskipun jumlah produksi berubah-ubah. biaya tetap adalah biaya yang tidak mempengaruhi produksi dan terus dikeluarkan walaupun produksi yang diperoleh banyak atau sedikit meskipun tidak melakukan produksi, besarnya biaya tidak bergantung pada besar kecilnya biaya produksi yang diperoleh. biaya tetap yang dikeluarkan dalam penelitian ini meliputi NPA (nilai penyusutan alat), dan biaya tranportasi.

Pendapatan merupakan suatu hasil dari usaha yang akan dinilai dari biaya yang dikeluarkan dan penerimaan yang diperoleh dengan cara penerimaan dikurangi biaya yang dikeluarkan dalam proses produksi. Pendapatan adalah selisih total penerimaan dan total biaya yang dikeluarkan oleh pelaku usahatani.

Tabel 1. Analisis Pendapatan Usaha Pembibitan Udang Vanname di Kabupaten Takalar

\begin{tabular}{|c|c|c|c|c|}
\hline No & Uraian & Jumlah & Harga (Rp/ekor) & Nilai (Rp) \\
\hline 1 & Produksi & 3.775 .000 & & \\
\hline 2 & Harga & 10 & & \\
\hline 3 & Penerimaan & & & 37.750 .000 \\
\hline 4 & Biaya Produksi & & & \\
\hline \multirow[t]{9}{*}{ A } & Biaya variabel & & & \\
\hline & Tenaga kerja (HOK) & 2 & 500.000 & 1.000 .000 \\
\hline & Benur/telur udang & 1.000 .000 & 1,3 & 1.300 .000 \\
\hline & Pakan/pelet & 5 & 180.000 & 900.000 \\
\hline & Pakan Artemia & 450 & 7.000 & 3.150 .000 \\
\hline & Transportasi & 5 & 216.667 & 1.083 .335 \\
\hline & Bensin & 5 & 10.000 & 50.000 \\
\hline & Kantong plastik & 1800 & 500 & 900.000 \\
\hline & Total biaya variabel & & & 8.383 .335 \\
\hline \multirow[t]{15}{*}{ B } & Biaya Tetap & & & \\
\hline & Baskom & 2 & 119.583 & 279.028 \\
\hline & Gayung Jolan & 2 & 81.667 & 183.750 \\
\hline & Pompa udara & 2 & 3.666 .667 & 6.111 .111 \\
\hline & Selang kecil & 1.038 & 800 & 830.000 \\
\hline & Ember & 3 & 119.167 & 397.222 \\
\hline & Terpal & 5 & 1.250 .000 & 5.625 .000 \\
\hline & Pompa Air & 1 & 2.133 .333 & 2.133 .333 \\
\hline & Timbangan & 1 & 287.500 & 287.500 \\
\hline & Tabung Oksigen & 1 & 1.025 .000 & 1.025 .000 \\
\hline & Pajak Lahan & & & 16.167 \\
\hline & Listrik & & & 536.667 \\
\hline & Total Biaya Tetap & & & 10.100 .981 \\
\hline & Total Biaya Produksi & & & 18.484 .316 \\
\hline & Pendapatan & & & 19.265 .684 \\
\hline
\end{tabular}

Sumber : Data diolah, 2019. 
Tabel 1 menjelaskan bahwa produksi pengusaha pembibitan udang vaname sebesar 3.775.000 ekor dengan harga Rp 10.00/Ekor. Biaya tetap rata-rata tertinggi yakni pembelian pakan artemia senilai Rp.3.150.000 dan terendah pembelian pelet dan kantong plastik, masingmasing senilai Rp.900.000,-.Sementara biaya tetap rata-rata tertinggi yakni pompa udara senilai Rp.6.111.111,- dan terendah timbangan senilai Rp.287.500,-.Sehingga pendapatan ratarata yakni Rp.19.265.684,-/panen.

\section{Efisiensi Pemasaran}

Pemasaran produk dinyatakan efesien secara relatif apabila dalam aktifitas pemasaran tersebut terjadi proses penciptaan atau peningkatan nilai tambah terhadap produk yang di pasarkan. Selain itu, bagaimana sistem pemasaran tersebut memberikan keuntungan yang sesuai dengan biaya yang di korbankan oleh pelaku atau pihak pemasaran yang terlibat dimana hal tersebut dapat di lihat dari besarnya nilai yang mampu mendorong petani untuk berproduksi.

Tabel 2. Efisiensi Pemasaran Udang Vaname di Kabupaten Takalar

\begin{tabular}{lrrr}
\hline \multirow{2}{*}{ Uraian } & \multicolumn{3}{c}{ Pemasaran/Transportasi } \\
\cline { 2 - 4 } & I & \multicolumn{1}{c}{ II } \\
\hline Biaya Pemasaran & 500.000 & 300.000 & 150.000 \\
Harga & 2.500 .000 & 1.600 .000 & 1.600 .000 \\
Efisiensi (\%) & 20 & 10 & 6 \\
\hline
\end{tabular}

Sumber: Data diolah, 2019.

Tabel 2. menunjukkan bahwa efisiensi pemasaran tertinggi diperoleh pada saluran pemasaran tingkat I yakni $20 \%$, diikuti saluran pemasaran II dan III masing-masing senilai 10 $\%$ dan $6 \%$.

\section{KESIMPULAN}

Produksi pengusaha pembibitan udang vaname sebesar 3.775.000 ekor dengan harga Rp 10.00/Ekor. Biaya tetap rata-rata tertinggi yakni pembelian pakan artemia senilai Rp.3.150.000 dan terendah pembelian pelet dan kantong plastik, masing-masing senilai Rp.900.000,.Sementara biaya tetap rata-rata tertinggi yakni pompa udara senilai Rp.6.111.111,- dan terendah timbangan senilai Rp.287.500,-.Sehingga pendapatan rata-rata yakni Rp.19.265.684,/panen. Sementara efisiensi pemasaran tertinggi diperoleh pada saluran pemasaran tingkat I yakni $20 \%$, diikuti saluran pemasaran II dan III masing-masing senilai $10 \%$ dan $6 \%$ / panen. 


\section{DAFTAR PUSTAKA}

Anonim 2003. SNI 01-7246-2006 Produksi Udang Vaname (Litopenaeus vannamei) di Tambak dengan Teknologi Intensif. BSN, Jakarta.

Ariyanto, D. 2004. Dinamika Budidaya Udang di Indonesia. Warta Penelitian Perikanan Indonesia. Vol. 1. hal. 6-10.

Endang. 2012. Model Prediksi Financial Distress Perusahaan. Polibisnis. Vol. 4, No. 2. hal. 110.

Haliman, R.W. dan D. Adijaya. 2005. Udang vannamei, Pembudidayaan dan Prospek Pasar Udang Putih yang Tahan Penyakit. Penebar Swadaya, Jakarta..

Hasibun, S.P. 2005. Analisis Efisiensi Teknis Usahatani (Suatu Kajian dengan Menggunakan Fungsi Produksi Frontier Stochastic). Jurnal Embryo.

Mulyadi, 2007. Sistem Perencanaan dan Pengendalian Manajemen,.Salemba Empat, Jakarta.

Soekartawi. 2006. Analisis Usahatani. Jakarta. Universitas Indonesia

Soekartawi. 1986. Ilmu Usahatani dan Penelitian untuk Pengembangan Petani Kecil. Penerbit UniversitasIndonesia: Jakarta.

Soekartawi, 1986. Agribisnis Teori dan Aplikasi. Rajawali Press. Jakarta

Subyakto, Murjadni,M., dan Subaidah, S. 2009. Status Budidaya Udang Introduksi di Jawa Timur. Laporan Balai Budidaya Air Payau Situbondo 